\title{
THE STUDY OF THE ANTIHYPOXIC ACTIVITY OF NEW DERIVATIVES OF BENZILIC ACID
}

\author{
I.V.Kireyev, S.V.Kolisnyk, N.M.Tryschuk, K.M.Sytnik \\ National University of Pharmacy
}

Key words: antihypoxic activity; derivatives of benzilic acid

On the model of acute normobaric hypoxic hypoxia with hypercapnia the antihypoxic action of new derivatives of benzilic acid, namely - N-heterylamides of benzilic acid and products of their intramolecular cyclodehydration - thienolactams with five-, six- and seven membered cycles, respectively. Amides have also been studied on the basis of five-membered lactam - derivatives of thieno[3,4-b]pyrrol6-carboxylic acid. According to the result of our studies the following regularities have been found. The cyclization products of benzilic acid amides significantly exceed the antihypoxic activity of the parent compounds, and it indicates the prospects of conducting the studies among the products of heterocyclization of $\mathrm{N}$ - heterylamides of benzilic acid. It should also be noted that modification of the ester group in position 6 of 2-oxo-3,3-diphenyl-2,3-dihydro-1H-thieno[3,4-b]pyrrole-6-carboxylic acid appeared to be appropriate. Amides based on this compound (KMS-68, KMS-69, KMS-71) during the experiment showed the maximum life span of the animals under research.

Hypoxia occurs with the lack of oxygen in the inhaled air and blood, as well as in disturbance of the biochemical processes of tissue respiration. Because of this oxygen deficiency the irreversible changes occur in organs. The central nervous system, heart muscle, kidney tissues, and liver are the most sensitive to the lack of oxygen.

To reduce hypoxia pharmacological products the methods that increase the supply of oxygen to the body and improve its utilization are used $[3,4]$. The aim of this work was to determine the antihypoxic activity of the new pharmacologically active compounds synthesized in the range of benzilic acid derivatives.

\section{Materials and Methods}

The object of the study of the antihypoxic action was the new group of compounds of benzilic acid derivatives synthesized at the Organic Chemistry Department of the National University of Pharmacy, namely - N-heterylamides of benzilic acid and products of their intramolecular cyclodehydration - thienolactams of five-, sixand seven membered cycles, respectively. Amides also were studied on the basis of five-membered lactam derivatives of thieno[3,4-b]pyrrol-6-carboxylic acid.

The studies of the antihypoxic activity of new derivatives of benzilic acid were conducted on the model of acute normobaric hypoxic hypoxia with hypercapnia (ANHHH). Determination was conducted according to the guidelines "Preclinical studies of drugs" edited by O.V.Stefanov in outbred mice weighing 20-26 g; they were kept in the vivarium of the Central Research Laboratory of the National University of Pharmacy in standard conditions on a normal diet with free access to food and water [5]. Animals were divided into 17 groups; 5 mice in each group. Animals in the groups under research received once an aqueous solution of the substance studied orally by gavage in the dose of $12 \mathrm{mg} / \mathrm{kg} 60 \mathrm{~min}$ before the experiment. Control animals were injected with the corresponding volume of saline. ANHHH was modelled by placing the mice in isolated containments. The observation lasted until the death of animals $[1,6,7]$.

The antihypoxic activity was assessed by the life span (min) in relation to the control taken as $100 \%$ by the formula:

$$
\mathrm{AA}=\mathrm{t}_{\mathrm{d}} / \mathrm{t}_{\mathrm{k}} \times 100 \%
$$

where: $\mathrm{AA}-$ is the antihypoxic activity $(\%) ; \mathrm{t}_{\mathrm{d}}-$ is the life span of the experimental animals; $t_{k}-$ is the life span of control animals [2].

The statistical processing of the research results was performed using Student's t-test. Differences were considered significant at $\mathrm{p}<0.05$.

\section{Results and Discussion}

The data obtained in the study of the antihypoxic activity of the new pharmacologically active compounds synthesized in the range of benzilic acid derivatives are given in Table and Fig. 1, 2. As seen from the results, 14 of the compounds studied showed the antihypoxic activity out of 16, including 13 compounds that caused significant changes. The most effective substances were amides of thieno[3,4-b]pyrrol-6-carboxylic acid (KMS-68, KMS-69, KMS-71), and thienolactams (KMS-229 and KMS-258). Introduction of substance KMS-68 led to $8.8 \mathrm{~min}$ increase of the life span of animals in the study group; it was by $73.68 \%$ more than in the control group. In animals treated with the dose of N-3-indolyl amide (KMS-69) and benzylamide (KMS-71) there was 8.3 and $8.4 \mathrm{~min}$ increase of the life span, respectively. It is by $69.32 \%$ and $69.90 \%$ above the control value. KMS-229 and KMS-258 also revealed the antihypoxic activity: they increased the life span of laboratory mice by $66.86 \%$ and $55.78 \%$, respectively.

It should be also noted that when introducing the original methyl ester (KMS-10) to the group of experimen- 
Table

The antihypoxic activity of the new pharmacologically active compounds synthesized in the series of benzilic acid derivatives

\begin{tabular}{|l|c|c|}
\hline \multicolumn{1}{|c|}{ Compound } & Life span, min & $\begin{array}{c}\text { Antihypoxic } \\
\text { activity, } \%\end{array}$ \\
\hline Control & $12.0 \pm 0.1$ & - \\
\hline KMS-10 & $11.6 \pm 0.2^{*}$ & $-3.70 \%^{*}$ \\
\hline KMS-19 & $13.2 \pm 1.2$ & $11.42 \%$ \\
\hline KMS-49 & $17.6 \pm 0.9^{*}$ & $46.75 \%^{*}$ \\
\hline KMS-68 & $20.8 \pm 1.3^{*}$ & $73.68 \%^{*}$ \\
\hline KMS-69 & $20.3 \pm 1.2^{*}$ & $69.32 \%^{*}$ \\
\hline KMS-70 & $16.7 \pm 1.3^{*}$ & $38.77 \%^{*}$ \\
\hline KMS-71 & $20.4 \pm 1.6^{*}$ & $69.90 \%^{*}$ \\
\hline KMS-73 & $15.5 \pm 2.0^{*}$ & $28.96 \%^{*}$ \\
\hline KMS-228 & $16.3 \pm 1.3^{*}$ & $35.71 \%^{*}$ \\
\hline KMS-229 & $20.0 \pm 1.5^{*}$ & $66.86 \%^{*}$ \\
\hline KMS-230 & $13.7 \pm 0.9^{*}$ & $14.37 \%^{*}$ \\
\hline KMS-258 & $18.7 \pm 1.4^{*}$ & $55.78 \%^{*}$ \\
\hline KMS-282 & $15.4 \pm 1.4^{*}$ & $28.22 \%^{*}$ \\
\hline KMS-283 & $15.1 \pm 0.7^{*}$ & $25.51 \%^{*}$ \\
\hline KMS-284 & $15.7 \pm 0.4^{*}$ & $31.01 \%^{*}$ \\
\hline KMS-303 & $11.0 \pm 1.6$ & $-8.23 \%^{*}$ \\
\hline
\end{tabular}

tal animals there was decrease of the antihypoxic activity by $3.70 \%$, and introduction of the six-membered cycle thienolactam (KMS-303), unlike seven-membered lactams, led to $1 \mathrm{~min}$ reduction of the life span of laboratory mice.

The analysis of statistically processed data concerning survival in ANHHH of laboratory animals showed that the most effective substances were KMS-68, KMS-69, KMS-71, KMS-229 and KMS-258.

Thus, according to the result of our studies the following regularities have been found: the cyclization products of benzilic acid amides significantly exceed the antihypoxic activity of the parent compounds. This tendency is observed in pairs: KMS-10 - KMS-19, KMS-228 KMS-229, KMS-230 - KMS-258, and indicates the prospects of conducting the studies exactly among the products of heterocyclization of N-heterylamides of benzilic acid. It should also be noted that modification of the ester group in position 6 of 2-oxo-3,3-diphenyl-2,3-

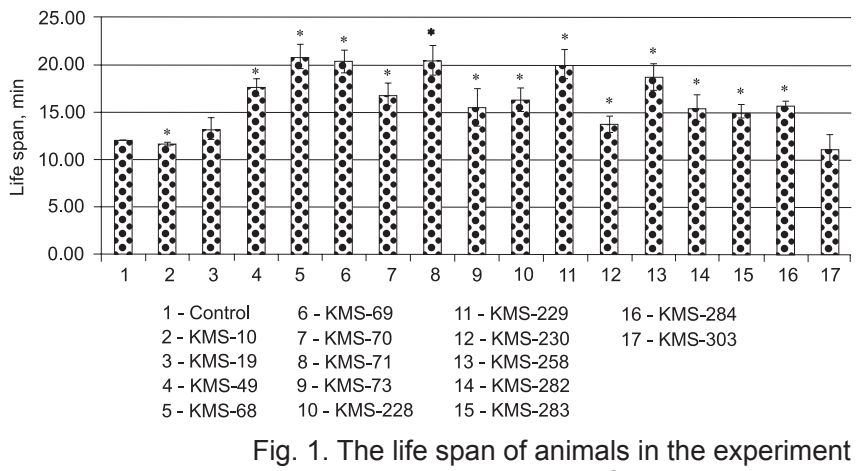

$\left({ }^{*}-p \leq 0.05\right.$ for control animals).

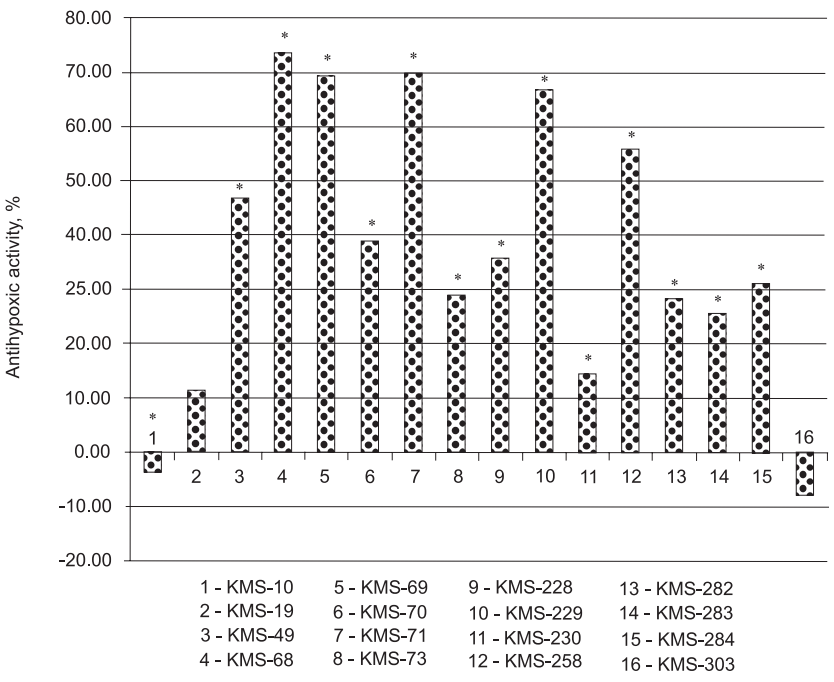

Fig. 2. The antihypoxic activity of the substances of benzilic acid derivatives under study ( ${ }^{*}-p \leq 0.05$ for control animals).

dihydro-1H-thieno[3,4-b]pyrrole-6-carboxylic acid appeared to be appropriate. Amides based on this compound (KMS-68, KMS-69, KMS-71) during the experiment showed the maximum life span of the animals under research. A slightly inferior activity was observed for seven-membered thienolactams - 5-oxo-6,6-diphenyl5,6-dihydro-4H-2-thia-4-asa-benzo[e]azulen-3-methylcarboxylates. Introduction of the chlorine atom in position 8 of the molecule resulted in an insignificant loss of the activity of compound KMS-258 compared to compound KMS-229.

\section{CONCLUSIONS}

1. On the model of acute normobaric hypoxic hypoxia with hypercapnia the antihypoxic activity of 16 new derivatives of benzilic acid have been studied.

2. The most active substance appeared to be KMS-68, its introduction led to increase of the life span of animals in the study group by $73.68 \%$ more than in the control group.

\section{REFERENCES}

1. Александрова А.Е. // Эксперимент. и клин. фармакол. - 2005. - Т. 68, №5. - С. 72-78.

2. Багаурі О.В., Редькін Р.Г., Ходаківський О.А. // Вісник фармації. - 2013. - №2. - С. 63-65.

3. Бекетов А.И., Сапегин И.Д., Полевик И.В. Экспериментальное (доклиническое) изучение фармакологических средств, влияющих на мозговое кровообращение: Метод. рекоменд. - К.: Авиценна, 2002. - 33 с.

4. Буреш Я., Бурешова О., Хьюстон Д.П. Методики и основные эксперименты по изучению мозга и поведения / Пер. с англ. Е.Н.Живописиевой. Под ред. А.С.Батуева. - М.: Выси. шк., 1991. - 399 с. 
5. Доклінічні дослідження лікарських засобів: Метод. рекоменд. / За ред. О.В.Стефанова. - К.: Авіченна, 2001. $-528 \mathrm{c}$.

6. Левченкова О.С., Новиков В.Е., Парфенов Э.А. // Вятский мед. вестник. - 2004. - №2-4. - С. 41-43.

7. Самойлов Н.Н., Стратиенко Е.Н., Байкалова Л.В. и др. // Вестник Рос. академии естественных наук. - 2008. - №3. - C. 71-73.

\section{ДОСЛІДЖЕННЯ АНТИГІПОКСИЧНОЇ АКТИВНОСТІ НОВИХ ПОХІДНИХ БЕНЗИЛОВОЇ КИСЛОТИ \\ І.В.Кіреєв, С.В.Колісник, Н.М.Трищук, К.М.Ситнік}

Ключові слова: антигіпоксична активність; похідні бензилової кислоти

На моделі гострої нормобаричної гіпоксичної гіпоксії з гіперкапнією досліджена антигіпоксична дія нових похідних бензилової кислоти, а саме - N-гетериламідів бензилової кислоти та продуктів їх внутрішньомолекулярної циклодегідратації - тієнолактамів з п'яти-, шести- та семичленними циклами. Також були досліджені аміди на основі п'ятичленного лактаму - похідні тієно[3,4-ь]пірол-6-карбонової кислоти. За результатами досліджень були встановлені наступні закономірності: продукти циклізації амідів бензилової кислоти значно перевищують за антигіпоксичною активністю вихідні сполуки, що вказує на перспективність проведення досліджень саме серед продуктів гетероциклізації $\mathrm{N}$-гетериламідів бензилової кислоти. Слід також зазначити, що доцільною виявилась модифрікація естерної групи в положенні 6 2-оксо3,3-дифреніл-2,3-дигідро-1Н-тієно[3,4-b]пірол-6-карбонової кислоти. Аміди на основі цієї сполуки (KMS-68, KMS-69, KMS-71) в ході експерименту максимально пролонговували тривалість життя піддослідних тварин.

\section{ИССЛЕДОВАНИЕ АНТИГИПОКСИЧЕСКОЙ АКТИВНОСТИ НОВЫХ ПРОИЗВОДНЫХ БЕНЗИЛОВОЙ КИСЛОТЫ \\ И.В.Киреев, С.В.Колесник, Н.М.Трищук, К.М.Сытник}

Ключевые слова: антигипоксическая активность; производные бензиловой кислоты

На модели острой нормобарической гипоксической гипоксии с гиперкапнией определена антигипоксическая активность новых производных бензиловой кислоты, а именно - N-гетериламидов бензиловой кислоты и продуктов их внутримолекулярной циклодегидратации - тиенолактамов с пяти-, шести и семичленными циклами. Также были исследованы амиды на основе пятичленного лактама - производные тиено[3,4-b]пиррол-6-карбоновой кислоты. В результате исследований были установлены следующие закономерности: продукты циклизации амидов бензиловой кислоты значительно превосходят по антигипоксической активности исходные соединения, что указывает на перспективность проведения исследований именно среди продуктов гетероциклизации N-гетериламидов бензиловой кислоты. Также следует отметить, что уместной оказалась модифрикация эфиирной группы в положении 6 2-оксо-3,3-дифренил-2,3-дигидро-1Н-тиено[3,4-ь]пиррол-6-карбоновой кислоты. Амиды на основе этого соединения (KMS-68, KMS-69, KMS-71) в ходе эксперимента максимально пролонгировали продолжительность жизни подопытных животных. 